\title{
Chemical Characterisation of the Industrial Residues of the Pineapple (Ananas comosus)
}

\author{
María Elena Sánchez Pardo1*, María Elena Ramos Cassellis², Rosalva Mora Escobedo, \\ Epifanio Jiménez García ${ }^{1}$ \\ ${ }^{1}$ Instituto Politécnico Nacional, Escuela Nacional de Ciencias Biológicas, Prolongación de Carpio y Plan de Ayala \\ S/N, Col. Sto. Tomás. C.P. 11340, México D.F., México \\ ${ }^{2}$ Benemérita Universidad Autónoma de Puebla, Av.San Claudio y 18 sur Edif.106, Ciudad Universitaria, Puebla, \\ Pue.3ExHacienda san Juan Molino, km 1.5 carretera Estatal Tecuexcomac-Tepetitla, México \\ Email: ${ }^{*}$ alimentoselena@hotmail.com
}

Received January 2014

\begin{abstract}
In Mexico pineapple processing produces industrial residues with a high concentration of dietary fibre. The aim of this study was to quantify the constituents of the fibrous residues from the industrial processing of pineapples which exhibited low concentrations of lignin.
\end{abstract}

\section{Keywords}

Pineapple; Total Dietary Fibre; Hemicelluloses; Cellulose; Lignin; Pectin

\section{Introduction}

Pineapple (Ananas comosus) is native to the South American continent and is considered an exotic fruit due to its taste and flavour. In Mexico, pineapple cultivation has a long tradition and is of vital economic and cultural importance [1]. Mexico is the seventh largest producer of pineapples worldwide. Pineapple residues can account for $50 \%$ of waste weight and generate approximately 10 tons/year of fresh fibre. Larrauri et al. reported that the external part of the pineapple has a significant content of soluble carbohydrates (as the product of the pulp remaining after removal of the edible part) including more than $20 \%$ total dietary fibre (TDF), composed mainly of hemicellulose.

The residual lignocellulosic fibres are polymeric materials of great industrial interest, because they are renewable and biodegradable products. Their chemical composition depends on the type and origin of the fibres which contain different amounts of cellulose, hemicellulose and lignin (dietary fibre). In addition to the amounts of dietary fibre present in the plant tissues other important aspects but also their chemical (degree of lignification, type and crystallinity of cellulose) and physical (particle size and shape) properties, because these affect fermentation in the colon as well as the speed of transit in the gastrointestinal tract.

Toward this objective, these residues were grouped as the leaf bracts, shell and core for a study of relationship between the native cellulose phases.

"Corresponding author.

How to cite this paper: Pardo, M.E.S., et al. (2014) Chemical Characterisation of the Industrial Residues of the Pineapple (Ananas comosus). Journal of Agricultural Chemistry and Environment, 3, 53-56. 


\section{Materials and Methods}

\subsection{Raw Materials: Treatment and Classification}

The residues were dehydrated in a horizontal drying chamber (Lumisell, Mexico, Mexico) at $60^{\circ} \mathrm{C}$ moisture content was less than $10 \%$.

\subsection{Proximate Chemical Analysis of Raw Materials}

Proximate chemical analysis for pulp and residues (leaf bracts, shell and core), was performed using the Association of Official Analytical Chemists (AOAC) [2]. The total protein was determined [\% $\mathrm{N} \times 6.25$ ] using method 993.19; total ash using method 955.04; crude fat using (method 920.39), moisture content using method 934.01, crude fibre using the acid-alkaline hydrolysis method 991.42, carbohydrates were determined (by subtration as the nitrogen-free extract, NFE).

The Insoluble (IDF) and soluble (SDF) dietary fibre contents were determined according to the AOAC method. The samples were dried, defatted and freed from carbohydrate, before the analysis. The (TDF) contents were corrected for residual protein, and ash. The total dietary fibre content was calculated as the sum of IDF and SDF.

Total dietary fibre (method 991.43) was performed according to the technique described in AOAC [2]. The samples were dried, defatted and free of carbohydrate. It was run blank through entire procedure along with samples to measure any contribution reagents to residue. In triplicate, $1 \pm 0.1 \mathrm{~g}$ of sample were suspended en 50 $\mathrm{mL}$ of phosphate buffer $\mathrm{pH}$ 6.0; submitted to enzymatic hydrolysis by $50 \mu \mathrm{L}$ of heat stable $\alpha$-amylase (A-3306, Sigma Chem. Co. St. Louis MO, USA) in boiling water bath for $30 \mathrm{~min}$. After cooling suspension to room temperature, $\mathrm{pH}$ was adjusted to $7.5 \pm 0.1$ and $100 \mu \mathrm{L}$ of protease (P-3910, Sigma Chem. Co. St. Louis MO, USA) was added and left to in water bath at $60^{\circ} \mathrm{C}$ for $30 \mathrm{~min}$. After cooling $\mathrm{pH}$ was adjusted to $4.5 \pm 0.1$ and $300 \mu \mathrm{L}$ of amyloglucosidase (A-9913 Sigma, Chem. Co. St. Louis MO, USA) were added.

The suspension was left to in water bath at $60^{\circ} \mathrm{C}$ for $30 \mathrm{~min}$. After that it was filtered to obtain the supernatant and the insoluble fraction. The supernatant was precipitated with 95\% alcohol to precipitate the SDF and it was quantified by drying overnight at $105^{\circ} \mathrm{C}$. The insoluble fraction was washed with $78 \%$ and $95 \%$ alcohol solutions and acetone, respectively, followed by drying overnight at $105^{\circ} \mathrm{C}$ to obtain the IDF. The dietary fibre contents were corrected for residual protein, ash and blank. The total dietary fibre was indicated as the sum of IDF + SDF.

To quantify the content of hemicellulose, the method for the determination of the neutral detergent fibre (NDF) content was used as described previously by Van Soest [3]. Consequently, this residue of this analysis was utilized to determine the content of cellulose and lignin called the acid detergent fibre (ADF), using method 973.18.

\subsection{Statistical Analysis of Data}

An analysis of variance was used applying Tukey's test $(\alpha=0.05)$ utilizing Statistical Analysis System 8.0 (SAS Institute Inc., Cary, North California, USA) software [4].

\section{Results and Discussion}

In Table 1 the proximate chemical composition of the pineapple pulp and residues (leaf bracts, shell and core) are shown. Statistical analysis revealed significant differences $(\mathrm{p} \leq 0.05)$ in the parameters total protein, ash and crude fat values. The total protein content ranged from $0.7 \mathrm{~g} / 100 \mathrm{~g}$ of leaf bracts to $1.58 \mathrm{~g} / 100 \mathrm{~g}$ of pulp; this total protein could be mainly attributed to hydroxyproline-rich glycoprotein, Because Bartolome and Ruperez [5] and Smith et al. [6] reported that the glycoproteins in the shells of fruits, are immersed in the primary cell wall forming a network of microfibrils with the cellulose [7]. The leaf bracts exhibited the highest ash content, which was twice that in the pulp; although the values reported by Chau and Huang [8] in orange peels (3.3 g/100g) are twice those of the pineapple's shell and core. One important consideration is that carbohydrate content was determined by calculation and may include simple sugars such as monosaccharides and disaccharides [9]. The highest content of crude fat was found in the edible fraction of the pulp, followed by the core (in the case of the residue), whereas the lowest concentration of crude fat was in the leaf bracts. 
Table 1. Proximate chemical composition of the residues pineapple (leaf bracts, shell, and core) compared with pulp of pineapple.

\begin{tabular}{ccccc}
\hline $\mathbf{( g / 1 0 0 g )}$ & Pulp & Leaf bracts & Shell & Core \\
\hline Total protein & $1.58 \pm 0.01^{\mathrm{d}}$ & $0.70 \pm 0.01^{\mathrm{a}}$ & $0.75 \pm 0.01^{\mathrm{b}}$ & $0.85 \pm 0.01^{\mathrm{c}}$ \\
Ash & $3.0 \pm 0.01^{\mathrm{b}}$ & $7.37 \pm 0.0^{\mathrm{d}}$ & $1.5 \pm 0.00^{\mathrm{b}}$ & $1.3 \pm 0.00^{\mathrm{a}}$ \\
Crude fat & $3.19 \pm 0.00^{\mathrm{b}}$ & $3.5 \pm .01^{\mathrm{c}}$ & $2.0 \pm 0.01^{\mathrm{a}}$ & $3.17 \pm 0.01^{\mathrm{b}}$ \\
Crude fiber $^{\mathrm{a}}$ & $24.14 \pm 0.01^{\mathrm{a}}$ & $62.5 \pm 0.00^{\mathrm{c}}$ & $65 \pm 0.00^{\mathrm{c}}$ & $47.6 \pm 0.00^{\mathrm{b}}$ \\
NFE $^{*}$ & $68.79 \pm 0.00$ & $25.93 \pm 0.02$ & $32.1 \pm 0.02$ & $47.08 \pm 0.01$ \\
\hline
\end{tabular}

${ }^{*}$ NFE $=$ Nitrogen-free extract. Results are given for dry basis and correspond to the average from three independent determinations \pm standard deviation. Different letters in the same row indicate statistically significant difference $(p \leq 0.05)$ after applying Tukey’s test.

Table 2. Comparison of the chemical composition of the pineapple residues (g/100g Dry weight).

\begin{tabular}{|c|c|c|c|}
\hline Fibre & Leaf bracts & Shell & Core \\
\hline IDF & $43.53 \pm 0.93^{\mathrm{a}}$ & $46.20 \pm 0.50^{b}$ & $42.92 \pm 0.09^{\mathrm{a}}$ \\
\hline SDF & $29.16 \pm 0.46^{\mathrm{b}}$ & $35.67 \pm 0.37^{c}$ & $21.27 \pm 0.61^{\mathrm{a}}$ \\
\hline TDF & 74.69 & 81.8 & 64.19 \\
\hline Hemicellulose & $21.88 \pm 0.22^{\mathrm{a}}$ & $28.69 \pm 0.35^{b}$ & $28.53 \pm 1.37^{\mathrm{b}}$ \\
\hline Cellulose & $43.53 \pm 1.17^{\mathrm{C}}$ & $40.55 \pm 1.02^{\mathrm{b}}$ & $24.53 \pm 1.68^{\mathrm{a}}$ \\
\hline Lignin & $13.88 \pm 1.70^{\mathrm{c}}$ & $10.01 \pm 0.38^{\mathrm{b}}$ & $5.78 \pm 0.429^{\mathrm{a}}$ \\
\hline Pectin & $2.32 \pm 0.37^{\mathrm{b}}$ & $2.49 \pm 0.20^{\mathrm{b}}$ & $1.58 \pm 0.17^{\mathrm{a}}$ \\
\hline
\end{tabular}

\subsection{Proximate Chemical Analysis}

The raw fibre contents ranged from $24.14 \%$, in the pulp, to $65 \%$, in the leaf bracts. As shown in Table 1, the raw fibre content of the residue fraction is 2.5 times greater than the edible fraction (pulp); these values are similar to those found by Larrauri et al. [10] and, Bartolome and Ruperez [5] who also studied pineapple shells.

\subsection{Determination of Soluble (SDF) and Insoluble (IDF) Dietary Fibre}

Table 2 shows the results obtained for the different dietary fibre fractions, the statistical analysis showed that significant differences $(\mathrm{p} \leq 0.05)$ exist among the leaf bracts, shell and core.

The content of dietary fibre (TDF) in the residue depended on the source from which it was extracted, with the shell having the highest content ( $81.8 \mathrm{~g} / 100 \mathrm{~g}$ of dry sample). This value is higher than that reported by Chau et al. [8] for orange residues and by Figuerola et al. [11] for grape peels.

Results are given for dry basis and correspond to the average from three independent determinations \pm standard deviation. Different letters in the same row indicate statistically significant difference $(\mathrm{p} \leq 0.05)$ after applying Tukey's test.

Furthermore, the main fibre fraction found in the residues studied fibres was the (IDF fraction) which represented $56 \%-65 \%$ of the TDF, similar to the value reported for orange peel [11], but greater than that reported for grape peels [9]. These results indicated that the samples tested were composed mainly of cellulose microfibrils containing hemicellulose and lignin [12], as shown in Table 2.

\section{Conclusion}

The agroindustrial pineapple residues had a greater fraction of fibre than the edible portion or pulp, and even more than other agroindustrial residues. The amount of dietary fibre found in the pineapple leaf bracts, shell and core residues, was relatively high and with the insoluble fraction being the main component.

\section{Acknowledgements}

MESP and RME are members of SNI and recipients of institutional grants (COFAA, EDD and EDI). The doctoral studies of MERC have been supported by CONACyT Mexico. 


\section{References}

[1] Olvera, J. (2013) Production of pineapple in Mexico.

[2] AOAC, Association of Official Analytical Chemists, 16, AOAC international, MD, USA, (1995).

[3] Van Soest, P.J., Robertson, J.B. and Lewis, B.A. (1991) Methods of Fietary, Neutral Detergent Fiber and Non-Starch Polusaccharides in Relation to Animal Nutrition. Journal of Dairy Science, 74, 3583-3597. http://dx.doi.org/10.3168/jds.S0022-0302(91)78551-2

[4] Montgomery, D. (2010) Introduction to Design of Experiments. 3rd Edition, Limusa-Wiley, México.

[5] Bartolome, A.P., Ruperez, P. and Prieto, A. (1995) Polysaccharides from the Cell Walls of Pineapple Fruit. Journal of Agricultural and Food Chemistry, 43, 608-612. http://dx.doi.org/10.1021/jf00051a010

[6] Smith, B. and Harris, P. (1995) Polysaccharide Composition of Unlignified Cell Walls of Pineapple [Ananas comosus (L.) Merr.] Fruit. Plant Physiology, 107, 1399-1409. http://dx.doi.org/10.1104/pp.107.4.1399

[7] Ai, L., Wu, J., Che, N., Wu, Y. and Cui, S.W. (2012) Extraction, Partial Characterization and Bioactivity of Polysaccharides from Boat-Fruited Sterculia Seeds. International Journal of Biological Macromolecules, 51, 815-818. http://dx.doi.org/10.1016/j.ijbiomac.2012.08.006

[8] Chau, C. F., Huang, Y. L. (2003) Comparison of the Chemical Composition and Physicochemical Properties of Different Fibers Prepared from the Peel of Citrus sinensis L. cv. Liucheng. Journal of Agricultural and Food Chemistry, 51, 2615-2618. http://dx.doi.org/10.1021/jf025919b

[9] Redgwell, R., Trovato, V., Merinat, S., Curti, D., Hediger, S. and Manez, A. (2003) Dietary Fibre in Cocoa Shell: Characterisation of Component Polysaccharides. Food Chemistry, 81, 103-112. http://dx.doi.org/10.1016/S0308-8146(02)00385-0

[10] Larrauri, J.A., Rupérez, P. and Calixto, F.S. (1997) Pineapple Shell as a Source of Dietary Fiber with Associated Polyphenols. Journal of Agricultural and Food Chemistry, 45, 4028-4031. http://dx.doi.org/10.1021/jf970450j

[11] Figuerola, F., Hurtado, M.L., Estévez, A.M., Chiffelle, I. and Asenjo, F. (2005) Fibre Concentrates from Apple Pomace and Citrus Peel as Potential Fibre Sources for Food Enrichment. Food Chemistry, 91, 395-401. http://dx.doi.org/10.1016/j.foodchem.2004.04.036

[12] Pawinee, Ch., Sakarindr, B. and Thammasat, M. (2001) Mesophilic and Thermophilic Anaerobic Digestion of Pineapple Cannery Wastes. International Journal Science Technology, 6, 1-9. 